\title{
Integrating project-based learning (PBL) in EFL learning: An effective tool to enhance the students' motivation
}

\author{
Ly Thi Tra My ${ }^{1}$, Nguyen ThiThuy Hang ${ }^{2}$, Ngo Thi Ngoc Thao ${ }^{3}$ \\ and Duong Thi Hoang Oanh ${ }^{4}$
}

\author{
1,2,3 Tay Do University, Cai Rang District, Can Tho City, Viet Nam, 900000 \\ ${ }^{4}$ RMIT University, District 7, Ho Chi Minh City, Viet Nam, 700071
}

\begin{abstract}
This article focused on presenting a brief study relevant to the employment of the project-based learning (PBL) approach in a language classroom and its effects on language students' motivation. The study utilized the mixed method approach with the triangulation of the three data collection instruments namely the questionnaire, interviews and observation. The research participants were students of English studying in their third year at the same university. The results confirmed that the PBL was an interesting and useful learning and teaching method that can help enhance the students' learning motivation and hence would need to be widely applied in the language learning and teaching process. The pedagogical implications indicate that educational institutions, teachers and students alike would need to apply this method more widely and comprehensively together with investing much time and effort in incorporate this method an indispensable component in their learning and teaching activities.

Key words: language learning and teaching, teaching methods, project-based learning, learning motivation.
\end{abstract}

\section{Introduction}

1.1 The significance of the study

Improving and upgrading teaching methodology in a sustainable manner has always been an indispensable task in teaching and learning English as a foreign language (EFL). In the effort to find and integrate more effective methods to teach EFL, the researchers have conducted an investigation into the effectiveness of the project based learning approach in English classes aiming to enhancing students' learning motivation. It is well known that no matter how interesting a method could be from the teacher's perfective, it would be meaningless once that it fails to motivate the students' learning attitude.

Moreover, the project-based learning approach has long been an appealing teaching method for the teachers since its emergence in the mid-1800s first created by David Snedden (Simpson, 2011). Generally speaking, project-based learning can bring about a great deal of benefits for the language learning process such as enhancing English language skills, self-confidence, developing the teacherstudent relationship, conducting interesting activities and obtaining career satisfaction (Thomas, 2000; Thao, 2009, Simpson, 2011; Thang, 2018).

This paper aims to find out whether and to which extent the project-based learning (PBL) can help develop the students' learning motivation and thus contribute to improving the quality of EFL learning and teaching.

\subsection{Research question}

With the primary objectives of investigating the effects that PBL would have on EFL students' learning motivation, this study aims to answer the following questions:

Can PBL enhance EFL students' learning motivation?

If yes, to what extent does the PBL enhance EFL students' learning motivation?

\section{Conceptual framework}

To start, this session deals with the background to this study, including relevant definitions, benefits of the PBL, learning motivation and its role in language learning. Furthermore, this part also tackles on decoding a fieldtrip and its role in educational activities, then relates the fieldtrip with the projectbased learning. 
2.1 Definitions of project-based learning approach.

Project-based learning (PBL) is a learning approach in which doing a project is the center of the learning process. According to Thomas' analysis (2000), PBL is a complex process, based on a challenging problem or a situation that requires learners to conduct research, design, solve the problem and make decisions in the sought of the answer.

Fried-Booth (2002) adds that PBL is a leanerscentered teaching method, considering learners as the center of the learning and teaching process. Learners are seen as creators of several products who are enabled and equipped to meet with the demand of real life. Such a process helps connect the theoretical knowledge provided by the school to what really happens in daily life.

In the case of Vietnam, Thao (2009) points out in her study that PBL is a teaching method in which learners under the facilitation of their teachers implement a complicated learning task with their groups. The task would require a great deal of individual as well as teamwork efforts in order to create products that can be used or displayed to the community. Furthermore, Thang (2018) claims that PBL is a teaching method in which students under the guidance of the teachers would deal with a situation or context from their own real life. The "situation" is selectively a combination of theory and practice, adhered to the learning program under the corporation of a group of students.

In short, PBL is a learning and teaching method in which the learners are considered to be the center of the learning process. The project is founded on a context arising from real life and relevant to the learning contents. Most importantly, learners are the main seekers for the answers to the problem under the guidance of the teachers.

\subsection{Benefits of the project-based learning approach}

The benefits of the project-based learning approach has been well documented. Studies have shown that real life materials promote the development of reading skills and reflect on how language is used (Berardo, 2006). This kind of assignment leads to multiple opportunities for students to develop the reading skill. In addition, Wee and Jacobs (2006) explain that students can develop their writing skill by writing, process-planning, drafting and revising during the project. The students collaboratively practice their writing and receive extensive peer responses leading to improvement in their writing capacity (Simpson, 2011). Moreover, thanks to the PBL, the students are offered chances to speak and listen to English used in a variety of language functions as they complete the project.
ISSN 2455-6378

Furthermore, the students' improvements in selfconfidence and learning motivation are found indispensable through the utilization of the projectbased learning. Accordingly, Fried-Booth (2002) claims that the process leading to the end-product of project-work provides opportunities for students to develop their confidence and independence as they need to communicate with their partners, teachers and interviewers to discuss, to elaborate for information and to seek advice as well as input for their projects. On the other hand, depending on the expected learning outcomes of each project, the learning approach will require the students to design their own project which aims to produce authentic output to contribute to the community. In such a process, the students would recognize the meaningfulness of their tasks and gain more motivation to do research and study further because the students' own choice and in control of the activities are critical to enhance the motivation to participate to and engage in classroom tasks (according to Deci\& Ryan, 1987; Lepper, 1988).

In conclusion, among many benefits that the projectbased learning can offer, the development of language skills, self - confidence and the improvement of motivation are seen to be the most prominent.

\subsection{Definitions of learning motivation and its role in language learning}

As can be seen in the previous part, motivation plays a fundamental role in an FLL process. Motivation is generally defined as a psychological trait which leads people to achieve certain goals. In language learning, that goal may be the mastery of the language, or the achievement of some lesser aim (Johnson, 1999). Chang (2005) further explains that language learning motivation is the degree to which one works or attempts to learn the language because of their desire to do so, and satisfaction obtained from the activity. In other words, motivation is commonly considered to be related to the learners' directed, reinforcing effort in learning a language; that is, the effort that a language learner is willing to make in the process of foreign language learning.

Regarding the role of motivation in language learning, it can be reinforced that motivation plays a significant role in the success of language learning in general and in classroom language learning in particular (Cook, 2000). Richards and Schmidt (2002) even confirm that motivation is generally considered to be one of the primary causes of success and failure in second or foreign language learning because motivation offers learners with an aim and direction to follow. The fact is that without a desire to learn, it is very difficult for learners to achieve effectiveness in learning. Hence, it is advisable to teachers that they would need to pay attention to 
motivate their learners by making appropriate changes in their teaching or else the learning and teaching process may lead to failure or without any positive effect.

\subsection{Definition of a fieldtrip, its meaning in an educational environment and its correlation with the project-based learning.}

The notion of fieldtrip has long been decoded by many researchers since it is an effective way to activate students' engagement into a learning and teaching process (Martin et al, 1981; Bogner, 1998; Preston and Griffiths, 2004, Dillon et al, 2006).

Stephen (2019) defines a field trip as a journey which usually involves a group of people to a place away from their usual environment. According to the researchers, such fieldtrips provide learners with opportunities to access the outside area of a traditional classroom and furthermore to explore other cultures and customs, to approach the motherland of the native languages, and experience the interesting local life.

In traditional classes, students often do not have an opportunity to learn in an amusing way and based on experience. In other words, too often the joy of learning is fading, and students learn how not to learn (Dryden and Vos, 2001). However, in a modern school, it is necessary for a student to be an active participant in the teaching process (Jensen, 2003). Therefore, teachers should try to find ways to motivate students to learn and enjoy the learning process at the same time. In this case, a fieldtrip can serve as an efficient alternative tool to trigger active learning and teaching.

As can be seen from the nature of a school fieldtrip and the project-based learning, there is a correlation between them. Specifically, both attempt at improving students' learning motivation and helping students become more independent in their studies. Moreover, they offer students opportunities to practice, and experience actual life activities out of a classroom. Therefore, they are likely to help fortify the student's learning involvement and outcomes. This is to say that it is reasonable for the combination between the school fieldtrip and the project-based learning in this study.

The following part will discuss the research methodology of this research, aiming to answer the two research questions as specified earlier.

\section{Research Methodology}

This part focuses on the methodology used for this research, discussing the rationale for using a mixed method approach, the research participants and instruments.
ISSN 2455-6378

\subsection{Mixed method approach}

To answer the research question, a mixed method approach was employed in this study. In other words, the best possible technique to adopt for this investigation was a triangulation of methods because triangulation can serve as an effective tool to eliminate possible bias such as (1) measurement bias (when the data are collected through a single source), (2) sampling bias (when all the population under study are not covered) and (3) procedural bias (when participants are put under some kind of pressure) (Yeasmin and Rahman, 2012).

\subsection{Research participants}

The research participants included 80 students majoring in the English language. Most of them came from the sub-Mekong area -an area, according to Nam, D., Thanh, T., \& Dung, P. (2017), still needed to enhance the quality of education and training since students of which still had low learning motivation and oftentimes dropped schools. At the time of participating in the study, the participants were in the first half of the third year. Most of them shared similar education background and moreover had never experienced the projectbased learning approach before. In this context, Vietnamese is the participants' mother tongue and English is their foreign language.

\subsection{Research instruments}

This study takes the form of a mixed method approach, making use of questionnaire, semi interview and observation to collect the valid and reliable data. Furthermore, a project-based activity was also used to help trigger the data

\subsubsection{A project-based activity - the fieldtrip}

Participating in a field trip is a compulsory activity in the study program of the research participants in their third year. The trip is aimed at providing opportunities for students to experience the job of a tour guide - one of the potential careers that students may pursuit after their graduation. To realize this plan, the school often designs a tour lasting 11 days in which the students will travel through different provinces from the Mekong Delta to the Middle of Viet Nam since this part of the country possesses many tourist attractions. The tour is often led by the school teachers and experienced tour guides who will explain the guiding techniques so that the students can become successful guides. After the trip, students are often asked to write essays reflected what they have learned to be a tour guide as well as their evaluation on the tour activities.

To turn the trip into a project, the trip organizers made several changes compared to the usual program. The students were asked to work in groups (four students in each group) to answer the question: "What can you do to advertise a tourist attraction in the trip that you're going to go?" After consulting with their teachers, each group's participants decided 
that the most convincing method to advertise tourist activities in a place was to let people feel and experience these things in a real and vivid way. In this case, making a video for assessment can be seen as an appropriate method to accompany the required essay. In the videos, students will play the roles of the tour guides who have good professional experience and provide vivid and insightful introduction about the place.

In brief, the project-based activity that was used in the study was actually the fieldtrip basically developed from that of the study program of the participants. In this project, students had to work in groups to find the answer for the question "What can you do to advertise a tourist attraction in the trip that you're going to go?" The expected products were a video and an essay for each group's participants.

\subsubsection{Questionnaire}

The questionnaire was designed in both English and Vietnamese. It contained 14 different questions asking detailed information about the students' learning motivation after the project. All questions were designed in 5-point Likert scale since "the intensity of a person's feelings is not dichotomous but is on a continuum between the extremes" (Wiersma, 2006).

\subsubsection{Semi-structured interviews}

In an attempt to obtain more information from the student respondents, semi-structured interview was employed since it can provide more information and assure the comparability of data (Kumar, 1996; Creswell, 2014). The interview consisted of two core questions seeking information on 1) the use of PBL in the students' classroom; and 2) the students' evaluation on the effects of PBL related to their learning motivation. Ten students were invited on a voluntary basis to participate in this part.

\subsubsection{Observation}

To verify the data collected from the questionnaire and interviews, observation was implemented in conjunction with the other two instruments. There were three meetings altogether. The first one was held before the field trip. The second one was conducted during the trip when students were asked to collect materials for their products. The last one was accomplished after the fieldtrip when the students worked in groups of four to finish their products. There were five observers; each observed two groups. When observing the students' work, the observers evaluated the students' learning motivation by ticking into the appropriate column of the checklist.

\section{Table 1. Observation checklist}

\begin{tabular}{|rl|l|l|l|l|l|}
\hline Ideas & Always & Usually & Sometimes & Rarely & Never \\
\hline 1. Students arrive at meetings on time & & & & & \\
\hline 2. Students prepare enough materials for the \\
meeting
\end{tabular}

\subsection{Data collection procedure}

Respondents took part in the fieldtrip. After the students handed in their products and received marks for their work, they were invited to answer the questions in the questionnaire and join the subsequent interviews on a voluntary basis. The observation was an ongoing process: during the time students prepared for the trip, went on the trip, as well as when they edited and finished the products after the trip.

The data collected from all the selective instruments were analyzed with the support of techniques from both qualitative and quantitative methods.

\subsection{Data analysis}

First of all, the data from the questionnaire and observation were quantitatively described with mean and standard deviation, as demonstrated in the following table.

Table 2. Interpretation of mean range

\begin{tabular}{|c|l|}
\hline Mean range & \multicolumn{1}{|c|}{ Interpretation } \\
\hline $4-5$ & High degree of motivation \\
\hline $3-3.9$ & Average degree of motivation \\
\hline $1-2.9$ & Low degree of motivation \\
\hline $1-1.9$ & Very low degree of motivation \\
\hline
\end{tabular}

Secondly, the interview data obtained from the openended questions would be analyzed in terms of frequency, percentage and also verbal report.

The results gained from the data collection and analysis are presented and discussed in the following section. 


\section{Results and Discussion}

In this part, the results from questionnaire, the findings from the interview and observation will be reported and analyzed.
4. 1. Results from the questionnaire

4.1.1. The usefulness of the project-based learning in the field trip

Table 3. The usefulness of the project-based learning in the field trip

\begin{tabular}{lccc}
\hline \multicolumn{1}{c}{ Ideas } & Mean & $\begin{array}{c}\text { Std. } \\
\text { Deviation }\end{array}$ & Meaning \\
\hline $\begin{array}{l}\text { 1. I think that this method of learning and teaching } \\
\text { English is very useful }\end{array}$ & 4.16 & .583 & High degree of motivation \\
\hline $\begin{array}{l}\text { 2. I will recommend this way of learning for other } \\
\text { students }\end{array}$ & 4.29 & .578 & High degree of motivation \\
\hline
\end{tabular}

The result from this table indicates that the students greatly evaluated the usefulness of PBL gained from their fieldtrip (Mean=4.16, $\mathrm{SD}=.583$ ). As a result, the students strongly supported the use of this method in their language classes (Mean= 4.29, $\mathrm{SD}=.578$,). In other words, the students were obviously highly

motivated in their leaning process with the PBL model.

\subsubsection{Improvements of the learning motivation}

Table 4. The comparison of learning motivation improvements

\begin{tabular}{|c|c|c|c|}
\hline Statements & Mean & SD & Meaning \\
\hline $\begin{array}{l}\text { 1. I become more responsible for my own learning after the } \\
\text { project }\end{array}$ & 4.38 & .537 & High degree of motivation \\
\hline 2. I become more self-started in learning English & 4.13 & .582 & High degree of motivation \\
\hline $\begin{array}{l}\text { 3. I see my learning more meaningful because my products } \\
\text { contribute to the development of the community. }\end{array}$ & 4.17 & .569 & High degree of motivation \\
\hline 4. I am more willing to study by this learning method. & 4.35 & .597 & High degree of motivation \\
\hline 5. I want to study more with this method. & 4.10 & .439 & High degree of motivation \\
\hline $\begin{array}{l}\text { 6. I look forward to getting involved in more projects like this } \\
\text { in the future }\end{array}$ & 4.13 & .460 & High degree of motivation \\
\hline 7. I want to study English more after the project & 4.05 & .650 & High degree of motivation \\
\hline 8. I feel proud of the products I made with my group & 4.12 & .460 & High degree of motivation \\
\hline $\begin{array}{l}\text { 9. I want to make more products like these to help my } \\
\text { country }\end{array}$ & 4.15 & .480 & High degree of motivation \\
\hline 10. The products I made motivate my study more & 4.10 & .467 & High degree of motivation \\
\hline 11. I feel proud of my use of English after the project & 4.18 & .414 & High degree of motivation \\
\hline $\begin{array}{l}\text { 12. I feel proud of myself on the completion of the project } \\
\text { because I could do things that I didn't think that I could do } \\
\text { before. }\end{array}$ & 4.14 & .522 & High degree of motivation \\
\hline $\begin{array}{l}\text { 13. I want to take part in more challenges in learning after this } \\
\text { project }\end{array}$ & 4.16 & .489 & High degree of motivation \\
\hline 14. I have more positive learning attitudes. & 4.09 & .396 & High degree of motivation \\
\hline
\end{tabular}

The 14 detailed ideas exemplifying different aspects of learning motivation were used to trigger the data about the improvement of students' learning motivation. Obviously, all the items were highly evaluated as seen from the table (Mean>4, SD>0.3), meaning that the students obtained high degree of motivation through the learning process with this method. Specifically, students recognized the meaningful values they were doing to contribute to the community while learning at school. As a result, they felt proud of themselves, and of the products they made. Moreover, the most striking result to emerge from the data is that students became more responsible for learning on their own $($ Mean $=4.38$, $\mathrm{SD}=.537$ ) hence they were more willing to study with this method in the future (Mean=4.35, $\mathrm{SD}=.597)$.

That students were more eager in learning, and experiencing new things, loved what they learned, and were proud of what they did is clear evidence 
that their learning motivation were much improved. Therefore, it can be concluded that the PBL helped students reinforced their strong learning motivation.

\section{2. Findings from the interviews}

\subsubsection{The employment of the PBL in students' classroom}

This part included the questions which asked whether students had ever studied with the PBL before. Several students admitted that they had heard of the method before whereas all the other respondents said that it had never been used in their English classroom:

NTHT: Yes, I used to hear about project-based learning approach in research methodology in English. However, my teacher hasn't taught us this method.

NTH: Yes, I heard about "Effects of the projectbased learning approach in English language learning in Tay Do University. And this is the first I have a chance to approach this way of teaching.

LMH: I haven't studied it yet

NPQ: My teacher hasn't taught us using the PBL in classes.

The data revealed that PBL was a new experience for the students.

\subsubsection{Students' evaluation on the effects of PBL in their learning motivation}

With this new learning experience, the students were encouraged to share how they evaluated the effects of this method on their learning motivation. The majority of the participants, eight students, agreed that this learning method gave them a lot of interest and motivated their commitment for studying English more. Meanwhile, the other two students said that they had no ideas and further explained that the method was new to them and it had so many things to work on.

NTTT: I appreciate the effect of this method on students' learning because this method helps participants improve many things such as improvements of language skills and improvements of learning motivation."

NPQ: Thanks to this method, I have added more experience for life and living, improve my communication ability. Moreover, I can upgrade some learning skills.
NTMT: This method is very useful. It helps my learning better. I felt more motivated.

LNHV: I love this method. It makes me interested in learning and I love our group's products.

NTD: This method is very interesting. I never think that I could make such an interesting video like this. I really looked forward to other projects in the future.

As it can be seen from the respondents' point of view, although the PBL was new and just recently applied to them, the majority of the participants found it greatly useful and interesting. More specifically, the claimed that they could improve their language skills, communication skills and most importantly they felt more motivated to learn further. Accordingly, they could upgrade their learning skills, felt more interested in learning, discovered for themselves that they could do things that they thought they had never been able to do before. Moreover, they loved what they had created after the project and looked for similar experience in the future. This is to say that the PBL can really help students to explore their own potential and competence, and certainly enhance their learning motivation in EFL.

\subsection{Findings from the observation}

The table 5 compares the results of the observation taking place in three different times. Generally speaking, the students' learning motivation developed gradually. More specifically, in the first meeting, all students showed that they had low motivation (all items were below 3, the low degree of motivation). However, in the second meeting, their motivation was observed to be better whereas all items had a value between 3 and 4 (the average degree of motivation). Finally, the last meeting reflected a significant increase in the students' motivation, i.e. they showed better interest in the meeting as well as the group work. While working in groups, they participated more actively and asked more questions relevant to the objectives of the group meeting. These items reflected a value higher or equal to 4 - the high degree of motivation. Nevertheless, some students still came late for meetings and did not prepare materials for the group work. This is to say that most students became more engaged in learning thanks to the method applied; whereas few students needed more time and energy to engage in such a dynamic process of learning. 
Table 5. Data of observation

\begin{tabular}{|c|c|c|c|c|c|c|c|c|c|}
\hline \multirow{2}{*}{ Ideas } & \multicolumn{3}{|c|}{ Fist observation } & \multicolumn{3}{|c|}{ Second observation } & \multicolumn{3}{|c|}{ Third observation } \\
\hline & Mean & SD & Meaning & Mean & SD & Meaning & Mean & SD & Meaning \\
\hline $\begin{array}{l}\text { 1. Students } \\
\text { arrive at } \\
\text { meetings } \\
\text { on time }\end{array}$ & 2.60 & 1.140 & $\begin{array}{l}\text { Low } \\
\text { degree of } \\
\text { motivation }\end{array}$ & 3.40 & .548 & $\begin{array}{l}\text { Average } \\
\text { degree of } \\
\text { motivation }\end{array}$ & 3.60 & 1.140 & $\begin{array}{l}\text { Average } \\
\text { degree of } \\
\text { motivation }\end{array}$ \\
\hline $\begin{array}{l}\text { 2. Students } \\
\text { prepare } \\
\text { enough } \\
\text { materials } \\
\text { for the } \\
\text { meeting }\end{array}$ & 2.60 & .894 & $\begin{array}{l}\text { Low } \\
\text { degree of } \\
\text { motivation }\end{array}$ & 3.20 & .447 & $\begin{array}{l}\text { Average } \\
\text { degree of } \\
\text { motivation }\end{array}$ & 3.80 & 1.304 & $\begin{array}{l}\text { Average } \\
\text { degree of } \\
\text { motivation }\end{array}$ \\
\hline $\begin{array}{l}\text { 3. Students } \\
\text { show } \\
\text { interest in } \\
\text { the meeting }\end{array}$ & 2.80 & 1.095 & $\begin{array}{l}\text { Low } \\
\text { degree of } \\
\text { motivation }\end{array}$ & 3.40 & .548 & $\begin{array}{l}\text { Average } \\
\text { degree of } \\
\text { motivation }\end{array}$ & 4.20 & .837 & $\begin{array}{l}\text { High level } \\
\text { of } \\
\text { motivation }\end{array}$ \\
\hline $\begin{array}{l}\text { 4. Students } \\
\text { show } \\
\text { interest in } \\
\text { group work }\end{array}$ & 2.80 & 1.304 & $\begin{array}{l}\text { Low } \\
\text { degree of } \\
\text { motivation }\end{array}$ & 3.40 & .548 & $\begin{array}{l}\text { Average } \\
\text { degree of } \\
\text { motivation }\end{array}$ & 4.20 & .837 & $\begin{array}{l}\text { High level } \\
\text { of } \\
\text { motivation }\end{array}$ \\
\hline $\begin{array}{l}\text { 5. Students } \\
\text { work } \\
\text { actively } \\
\text { with the } \\
\text { groups } \\
\end{array}$ & 2.40 & 1.140 & $\begin{array}{l}\text { Low } \\
\text { degree of } \\
\text { motivation }\end{array}$ & 3.40 & .548 & $\begin{array}{l}\text { Average } \\
\text { degree of } \\
\text { motivation }\end{array}$ & 4.40 & .548 & $\begin{array}{l}\text { High level } \\
\text { of } \\
\text { motivation }\end{array}$ \\
\hline $\begin{array}{l}\text { 6. Students } \\
\text { often ask } \\
\text { questions } \\
\text { relevant to } \\
\text { the task of } \\
\text { the group }\end{array}$ & 2.80 & 1.304 & $\begin{array}{l}\text { Low } \\
\text { degree of } \\
\text { motivation }\end{array}$ & 3.40 & .548 & $\begin{array}{l}\text { Average } \\
\text { degree of } \\
\text { motivation }\end{array}$ & 4.00 & 1.000 & $\begin{array}{l}\text { High level } \\
\text { of } \\
\text { motivation }\end{array}$ \\
\hline
\end{tabular}

\subsection{Discussion}

\subsubsection{The new method applied to students}

The first and foremost important conclusion that this study has found out is that although the project-based learning approach is new to students and requires a number of challenging tasks, the great majority of the students agreed that this method is useful and hence should be multiplied for wider use in EFL classes. This can be seen from the results of the questionnaire and interviews in which they students admitted that although they had already heard of this method, it was the first time they could experience it in authentic learning process and environment, and were convinced that PBL was an effective means for learning and applying English in real life and career.

4.4.2. The effects of the PBL on the students' learning motivation

The findings above share a number of similarities with the studies of Deci \& Ryan (1987), Lepper (1988) and Simpson (2011) from the perspective that the participants' motivation was properly amplified with the use of PBL.
First, it is obvious from the results of the questionnaire that students were more engaged in their learning EFL after the project. Specifically speaking, students were more self-started and responsible for their learning. This is essential because only when they are well aware of the benefit of their own learning, they will be able to identify and specify the targets of their learning as well as make plans to achieve their goals. Moreover, students recognized their improvements after completing all the tasks of the projects, they felt proud of themselves, of what they had done, combining learning and career-oriented activities. As a result they could see the significance of their study and had more motivation to invest in their studies. Most importantly, after the project students did not feel tired or discouraged after accomplishing a series of stressful tasks in a short time, but eager to continue to work on more projects, to experience new challenges and explore more learning and work opportunities. This is actually meaningful to the learning and teaching activities as the method has been able to create opportunities for students to 
discover their hidden talents and inspired learners to take challenges without any fear or hesitation.

Next, the data of the interviews and observations also support what the questionnaire has found out. Generally speaking, respondents admitted that although it was the first time they had such a challenging task to work on in their study, the PBL had strongly provided them a great opportunity to experience life, apply what they learned into reality and more importantly to discover a new person in them - a person they think that they could have never known of without the stimulation of the project. To support the finding, the data of the observation witnessed a better learning motivation of the students day after day. In more specific terms, it can be seen that if in the first meeting, the students did not prepare well for their tasks with their groups, in the other subsequent meetings they were better prepared and engaged much more deeply in the process of group work.

These findings provided considerately significant evidence for the fact that the project-based learning enhances student's learning motivation. As a result, the method should be applied more widely in EFL classrooms to enhance the quality of the learning and teaching activities.

\section{Conclusions and Implications}

\subsection{Conclusions}

On the one hand, the recognition on the motivation improvements that PBL can bring to students of EFL and the fact that this method has not been employed widely in the language learning and teaching process have been the two most important premises for the implementation of the current study. The mixed method approach with the triangulation of the questionnaire, interviews and observations has helped to find out important findings that can contribute a great deal to the activities of language learning and teaching.

As a result, it can be reinforced that although PBL is still new to certain subjects in language learning and teaching, this learning method is found to be interesting and applicable in language classes. Furthermore, the application of this method in EFL can help to improve students' learning motivation which is of fundamental significance in the acquisition of a foreign language. This is not to mention some other benefits that the method can also bring about in the same respect which can be further researched in another study. For example, potential research topics may account for an investigation into students' self-exploration of self-strength or a survey about the improvements of the interpersonal relationship in group work throughout a projectbased activity. Students' being more engaged in designing activities or in exploring potentials for career development and paths through the employment of the project-based learning can also be interesting topics to study about.

In conclusion, the discussion above is hoped to bring those who may potentially be engaged in this method useful sharing so that they can use these to make better application for their classes. This method may also be applicable in different types of classes. To ensure this, it is suggested that further research can be conducted on the effects of this method as well as other aspects as discussed earlier in other classes of the language field or those in other fields.

\subsection{Implications}

The findings of the study help to withdraw some pedagogical implications to both the school, the teachers and students alike.

First of all, since this approach is beneficial and applicable in a tertiary education, it is recommended that the higher institution multiplies the employment of the method in other specializations. Moreover, it is important that the school provides essential conditions such as necessary materials, facilities, and flexible schedules so that meaningful and durable learning can happen.

Second, in order to apply the method thoroughly, it is necessary that both the teachers and the students obtain a clear understanding about the method. Therefore, it is advisable that the school and the teachers who have ever applied this method hold seminars about the employment of the project-based learning on a regular basis. This can not only help popularize the method but also provide necessary materials for potential applicants

In addition, further training on necessary skills and techniques during the application of the method should be conducted before the initiation of the method. This is to help students prepare better and be able to adopt and adapt themselves to the method as soon as possible after it is applied.

It is clear thorough the study that the PBL requires a lot of efforts from both the teachers as well as the students. In order to achieve best results of the method, it is advisable that the teachers should agree to commit and engage with students during the time they work on the project tasks as they always need successive encouragement to complete the work successfully.

Last but not least, the ultimate purpose of every effort is to try to improve the EFL activities of the students. Therefore, the students are advised to be brave enough to experience the new learning approach. They themselves must take responsibility of their own learning and wish to change their learning style in a positive way. Only when they themselves want to experience the method; they can overcome all the potential obstacles mentioned to achieve a worthy learning result. 


\section{References}

[1] Abrahams, I. (2009). Does Practical Work Really Motivate? A study of the affective value of practical work in secondary school science, Ian Abrahams, International Journal of Science Education, Volume 31, Issue 17, 2335 - 2353.

[2] Ballantyne, R., Packer, J. (2002). Nature-based excursions: School students' perceptions of learning in natural environments. International Journal of Geographical and Environmental Education 11 (3), 218-36.

[3] Berardo, S. A. (2006). The Use of Authentic Materials in the Teaching of Reading: Link Success. The Reading matrix, 6 (2). Retrieved December, 10th, 2010 from http://www.readingmatrix.com/ articles/berardo/article.pdf.

[4] Bogner, F.X. (1998). The influence of shortterm outdoor education on long- term variables of environmental perspective, Journal of Environmental Education 29 (4), pp.17-29.

[5] Chang, H. H. (2005). The relationship between extrinsic/intrinsic motivation and language learning strategies among college students of English in Taiwan. Available at: http://ethesys.lib.mcu.edu.tw/ETD-db/ETDsearch/getfile?URN=etd-0725105105417\&filename=etd-0725105-105417.pdf

[6] Cook, V. (2000). Linguistics and second language acquisition. Beijing: Foreign Language Teaching and Research Press and Macmillan (Publishers) Ltd.

[7] Creswell, J. W. (2014). Research design: qualitative, quantitative, and mixed methods approaches. (4th Ed). Thousand Oaks, California: SAGE Publications.

[8] Deci, E. L., \& Ryan, R. M. (1987). The support of autonomy and the control of behavior. Journal of Personality and Social Psychology, 53, 10241037.

[9] Dillon, J., Rickinson, M., Teamey K., Morris, M., Choi, M.J., Sanders, D. and P. Benefieldb (2006); The value of outdoor learning: evidence from research in the UK and elsewhere, School Science Review, March, 87(320)

[10]Dryden, G., Vos, J. (2001.).The Learning Revolution; Zagreb, Educa.

[11]Fried-Booth, D. L. (2002). Project Work. (2nd ed.). New York: Oxford University Press.

[12] Jensen, E. (2003). Super Teaching: teaching strategies for quality education and successful learning, Zagreb, Educa.

[13] Johnson, K., and Johnson, H. (eds.) (1999). Encyclopedic Dictionary of Applied Linguistics. Oxford: Blackwell Publishers Ltd

[14] Kumar, R. (1996). Research Methodology: a Step-by-step Guide for Beginners, Sydney: Longman.

\section{ISSN 2455-6378}

[15]Lepper, M. R., \& Chabay, R. W. (1988). Socializing the intelligent tutor: Bringing empathy to computer tutors. In H. Mandl \& A. M. Lesgold (Eds.), Learning Issues for Intelligent Tutoring Systems (pp. 242-257). Chicago: Springer-Verlag.

[16] Martin, W. W., Falk, J. H., Balling,J.D. (1981). Environmental effects on learning: the outdoor field trip. Science Education, 65(3), pp. 301309.

[17] Nam, D., Thanh, T., \& Dung, P. (2017). Cải thiện chất lượng giáo dục - đào tạo vùng đồng bằng sông Cửu Long. Báo Nhân Dân (Điện tử) Cơ quan trung ương của Đảng Cộng Sản Việt Nam, Tiếng nói của Đảng, Nhà nước và Nhân dân Việt Nam. 27 July, p 2.

[18] Preston, L., Griffiths, A. (2004). Pedagogy of connections: Findings of a collaborative action research project in outdoor and environmental education, Australian Journal of Outdoor Education, July.

[19] Richards, J.C. and Schmidt, R. (2002) Longman Dictionary of Language Teaching \& Applied Linguistics (3rd edition). Essex: Pearson Education Limited.

[20] Rickinson, M., Dillon, J., Teamey, K., Morris, M., Choi, M. Y., Sanders, D. and Benefield, P. (2004). A review of research on outdoor learning. Preston Montford, Shropshire: Field Studies Council.

[21] Scott, W., Gough, S. (eds) (2003). Sustainable Development and Learning: Framing the Issues. London: Routledge Falmer.

[22] Simpson, J. (2011). Integrating Project-Based Learning in an English Language Tourism Classroom in a Thai University. Doctoral Thesis, Australian Catholic University.

[23] Stephen (2019). What is Field Trip? Definition of Field Trip in Education. [Internet]. Available from

<https://www.educationalschooltrip.com/whatis-field-trip-definition-of-field-trip-ineducation/> [accessed 18 August 2020]

[24] Thomas, J.W. (2000). A Review of Research on $P B L$. Available from: http://www.bobpearlman.org/BestPractices/PBL .Research.pdf/ [accessed 17 July 2012]

[25] Thang, P M. (2018). Vận dụng phuơng pháp dạy học theo dụ án đối với môn giáo dục công dân khối 11 tại truờng trung hoc thực hành - đại họ su phạm thành phố hồ chí minh, Tạp chí Khoa học Trường Đại học Sư phạm TPHCM, tập 15, số (1): 162-172.

[26] Thao, N.T.D . (2009). Dạy học theo dự án và vận dụng trong đào tạo giáo viên Trung $h$ ọc cơ sở môn công ngh ệ. Luận án Tiến sĩ Giáo dục học, Đại học Sư phạm Hà Nội.

[27] Wee, S., \& Jacob, G. M. (2006). Implementing cooperative learning with secondary school 
students. In S. G. McCafferty, G. M. Jacobs \& A. C. Dasilva-Iddings (Eds.), Cooperlative Learning and Second Language Teaching (pp.113-132). New York: Cambridge University Press.

[28] Wiersma, W. (2006). Research Methods in Education: An Introduction. Boston, Mass: Pearson/ Allyn and Bacon.

\section{ISSN 2455-6378}

[29] Yeasmin, S., \& Rahman, K.F. (2012). Triangulation Research Method as the Tool of Social Science Research. BUP Journal, 1(1), 154-164.

[30] Zaklin, Diana and Ines (2010). Project-Based Learning and Field Study. Scientific project "Competences of pupils attending science and biology classes" No. 119-0091361-1223, Education and Sports of the Republic of Croatia 
APPENDIX A

Questionnaire

I am Ly Thi Tra My, lecturer of English at Tay Do University. I am carrying out the research on the effects that PBL may have on student's learning motivation. This questionnaire is aimed at collecting students' perception about the use of the project-based learning in their field trip. All the responses are used for research purposes only and the personal information of the participants is promised to keep confidential.

2. Participants' personal information:

Your name:

Your class:

Your gender: $\square$ male

$\square$ female

These questions ask you about the effects that the PBL had on you after the project, tick $(\checkmark)$ the most appropriate answers to you in each cluster

\begin{tabular}{|c|c|c|c|c|c|}
\hline \multirow{2}{*}{$\begin{array}{l}\text { Statements } \\
\text { PART 1. THE USEFULNESS OF THE METHOD }\end{array}$} & SA & $\mathrm{A}$ & NI & $\mathrm{D}$ & SD \\
\hline & & & & & \\
\hline 1. I think that this method of learning and teaching English is very useful & & & & & \\
\hline 2. I will recommend this way of learning for other students & & & & & \\
\hline $\begin{array}{l}\text { PART 2. THE EFFECT OF THE METHOD ON STUDENTS' LEARNING } \\
\text { MOTIVATION }\end{array}$ & & & & & \\
\hline 3. I become more responsible for my own learning after the project & & & & & \\
\hline 4. I become more self-started in learning English & & & & & \\
\hline $\begin{array}{l}\text { 5. I see my learning more meaningful because my products contribute to the } \\
\text { development of the community. }\end{array}$ & & & & & \\
\hline 6. I am more willing to study by this learning method. & & & & & \\
\hline 7. I want to study more with this method. & & & & & \\
\hline 8. I look forward to getting involved in more projects like this in the future & & & & & \\
\hline 9. I want to study English more after the project & & & & & \\
\hline 10. I feel proud of the products I made with my group & & & & & \\
\hline 11. I want to make more products like these to help my country & & & & & \\
\hline 12. The products I made motivate my study more & & & & & \\
\hline 13. I feel proud of my use of English after the project & & & & & \\
\hline $\begin{array}{l}\text { 14. I feel proud of myself on the completion of the project because I could do } \\
\text { things that I didn't think that I could do before. }\end{array}$ & & & & & \\
\hline 15. I want to take part in more challenges in learning after this project & & & & & \\
\hline 16. I have more positive learning attitud & & & & & \\
\hline
\end{tabular}

Notes: $\mathrm{SA}=$ Strongly Agree; $\mathrm{A}=$ Agree; $\mathrm{NI}=$ No idea; $\mathrm{D}=$ Disagree; $\mathrm{SD}=$ Strongly Disagree

APPENDIX B

OBSERVATION CHECKLIST

\begin{tabular}{|c|c|c|c|c|c|}
\hline Ideas & Always & Usually & Sometimes & Rarely & Never \\
\hline Students arrive at meetings on time & & & & & \\
\hline $\begin{array}{l}\text { Students prepare enough materials for the } \\
\text { meeting }\end{array}$ & & & & & \\
\hline Students show interest in the meeting & & & & & \\
\hline Students show interest in group work & & & & & \\
\hline Students work actively with the groups & & & & & \\
\hline $\begin{array}{l}\text { Students often ask questions relevant to } \\
\text { the task of the group }\end{array}$ & & & & & \\
\hline
\end{tabular}

\section{APPENDIX C \\ QUESTIONS FOR INTERVIEWS}

1. Have you ever heard and studied with the project-based learning approach before?

If yes, for what subject?

2. Do you think that the PBL motivated your English learning after the project? Why or why not? 